\title{
The Influence of Zn and Cd Accumulation on the Growth and Development of Medicinal Plants in the Impact Zone of the Novocherkassk Power Station
}

\section{Victor Chaplygin, Tatiana Minkina, Saglara Mandzhieva, Dina Nevidomskaya, Natalia Chernikova and Alexey Sherstnev}

Southern Federal University, Rostov-on-Don, Russia

ORCID ID:

Victor Chaplygin 0000-0002-1142-7750

Saglara Mandzhieva 0000-0001-6000-2209

Dina Nevidomskaya 0000-0002-0138-4443

Tatiana Minkina 0000-0003-3022-0883

Corresponding Author: Victor

Chaplygin; email:

chaplygin@sfedu.ru

\section{Dates}

Published 13 January 2022

Publishing services provided by

Knowledge E

(c) authors. This article is

distributed under the terms of

the Creative Commons

Attribution License, which

permits unrestricted use and

redistribution provided that the

original author and source are

credited.

Selection and Peer-review under the responsibility of the 8th

Scientific and Practical

Conference Conference Committee.

\begin{abstract}
Over the pastdecade, particular attention has been paid to studies of the chemical composition of medical plants to identify the possible negative consequences of using raw plant material polluted with heavy metals for the production of medical drugs. In our study, we analyzed the chemical composition of the medical plants growing in the impact area of the Novocherkassk power station. Specifically, the plants Artemisia austriaca, Poa pratensis and Elytrigia repenswere examined for the analysis. The content and distribution of $\mathrm{Zn}$ and $\mathrm{Cd}$, which are most distributed in industrial emissions and belong to the first class of hazardous elements, were measured. The maximum permissible content (MPC) of $\mathrm{Zn}$ in the raw material of Artemisia austriaca and Elytrigia repens was found, as was the maximum content of $\mathrm{Cd}$ in all analyzed plants growing in the $5 \mathrm{~km}$ area around thepower station. The plant Artemisia austriacawasfound to have $\mathrm{Zn}$ and $\mathrm{Cd}$ accumulation in itsabovegroundcomponents, while in Poa pratensis and Elytrigia repens, accumulation was in the roots. The morphobiometric parameters of the plants were mostly dependent on the soil properties, followed by the degree of technogenic load. The content of $\mathrm{Zn}$ and $\mathrm{Cd}$ in the medical drugs was higher than the MPC without visible features of heavy metal pollution and so these plants weredangerous for human health.
\end{abstract}

Keywords: heavy metals, technogenic load, phytoreagents, morphometric parameters

\section{Introduction}

Environmental pollution with potentially hazardous elements is one of urgent problems. Emissions of the chemical and energy industries are main sources of heavy metal (HM) pollution of the environment which are most toxic even in trace amounts [1, 8, 9], able to accumulate in the objects and keep the toxic effect over long time.

In present, the studies of the elemental chemical composition of medicinal plants are important and relevant due to constantly rising interest to herbal medicine over last decade as a complex of relatively simple technologies for prevention and medical 
treatment using medicinal plants $[2,10]$. Higher attention of the plant medical drugs (phytodrugs) is determined by constantly rising side effects on modern synthetic medicines and overall lack of the drugs for the treatment of chronic and long-term diseases. Therapy using phytopreparations has a great advantage, but there is a possibility of insufficiently effective and appearance of side effects of herbal medicines associated with the poor quality of medicinal raw materials and final products.

$\mathrm{Zn}$ and $\mathrm{Cd}$ are most distributed among industrial emissions of $\mathrm{HMs}$ belonging to the first hazard class. Cd is one of the most toxic elements with multiple toxic effects on plants [11] and $\mathrm{Zn}$ is one of important trace elements for the plant physiology which has been studied by various researchers [7].

The Novocherkassk Power station(NchPS) is largest enterprise polluting the environment with heavy metals which emissions are $1 \%$ of overall pollution of atmosphere in Russia, 50 \% of Rostov region, and $90 \%$ of Novocherkask city [5]. The NchPSemissions are also containing $\mathrm{Cd}$ and $\mathrm{Zn}$ [4]. Since NchPSis negatively affects the environment in surrounding areas over last 50 years, this region was selected as the study object.

\section{Materials and methods}

The monitoring sites were laid on the $1-20 \mathrm{~km}$ distance from NchPS. The monitoring sites were also chosen due to the growth of all studied species of medicinal herbaceous plants. The sites were located towards northwestern wind direction and adjacent northnorthwestern (no. 4, no. 5, nos. 8-10). The sites nos. 1-3, no. 7, nos. 1-14 were laid on the distance $1-3 \mathrm{~km}$ from NchPS in various wind directions and outside the prevailing wind direction (Fig. 1). Site no. 9 was chosen as the background (control) site due to its great distance $(15 \mathrm{~km})$ from NchPS and the absence of additional sources of pollution. Soils of the sites were represented by alluvial soil (Calcaric Fluvic Arenosols) (nos. 2, 12), meadow chernozem (Calcaric Fluvisols Loamic) (nos. 3, 6, 8, 11) and ordinary chernozem (Haplic Chernozem)divided into slightly polluted (nos. 1, 7, 9, 10, 13, 14) and polluted (nos. $4,5)$ due to uneven distribution of technogenic emissions over the territory.

The plants Artemisia austriaca Pall. ex. Wild., Poa pratensis L. and Elytrigia repens (L.) Nevski were sampled in the second decade of June during mass flowering and analyses for the $\mathrm{Cd}$ and $\mathrm{Zn}$ content. The mineralization of samples was carried out by the dry ashing method according to GOST 26929-94. To extract HMs, the ash samples were diluted in $20 \% \mathrm{HCl}$ and analyzed by atomic absorption spectrometry [3]. Evaluation of the plant pollution with HMs was performed by comparison of HM content in the plants with maximum permissible content (MPC) (50.0 and $0.1 \mathrm{mglkg}$ for 
Zn and Cd respectively) for raw plant material according to SanPiN 2.3.2.560-96. To analyze the effect of technogenic burden and soil type on the plant, all plant species were measured the morphometric parameters: total length, length of the stem, leaves, roots and inflorescences.

\section{Results and discussion}

The maximum content of the studied metals was observed in the sites located closest to the source of pollution along the line of the prevailing direction of the wind rose (nos. 4,5 and 6) and the content decreased with the increase of the distance from pollution source from the source in northwestern direction (sites nos. 8, 9, 10). Plants from the sites located in 1-2 km from NchPS as well as in other directions (nos. 1, 11, 12) were less polluted than on the sites of the prevailing wind direction that is related with site location out of prevailing wind rose zone and lower pollution. In total, the pollution with $\mathrm{Zn}$ and $\mathrm{Cd}$ was lower towards the south from the enterprise.

The plans of Artemisia austriaca (up to $3.1 \mathrm{MPC}$ ) and Elytrigia repens (up to 2.5 MPC) characterized with lower content of $\mathrm{Zn}$ on the sites nos. 4-6 with insufficient technogenic load (Fig. 1). The pollution of the Poa pratensiswith Zn was not determined since the exceeding the MPC level of $\mathrm{Zn}$ in raw plant materials can be determined only in conditions of maximum technogenic load while the content of $\mathrm{Zn}$ approximately corresponded to background site.Zn accumulation in Artemisia austriaca occurred mainly in aboveground part and in root system of Elytrigia repens and Poa pratensis. However, it is these plant parts that are used for production of medical drugs. The maximum $\mathrm{Zn}$ content was noted in Artemisia austriaca and minimum in Poa pratensis. The $\mathrm{Zn}$ content was two times higher of $\mathrm{Cd}$ concentration in all plants that is related with high demand of the plants in this element involved in several biological functions. However, the Zn content was significantly low in the studied plants.

The $\mathrm{Cd}$ content exceeding MPC in all plant species and reached 28.8 times for Artemisia austriaca, 10.1 Poa pratensis, and 12.0 for Elytrigia repens (Fig. 2). The clear dependence of pollution on localization of the monitoring sites was noted. Insignificant exceeding of MPC and close to Cd content limits was identified for Artemisia austriaca within the 5-km zone of pollution. $\mathrm{Cd}$ and $\mathrm{Zn}$ have accumulated mostly in aboveground parts of Artemisia austriaca, and in the root system of Elytrigia repens and Poa pratensis that characterizes this metal as extremely dangerous pollutant for medical plant material taking into account the high pollution levels of these plants. The maximum concentration of $\mathrm{Cd}$ was determined in Artemisia austriaca and the minimum in Poa pratensis. 


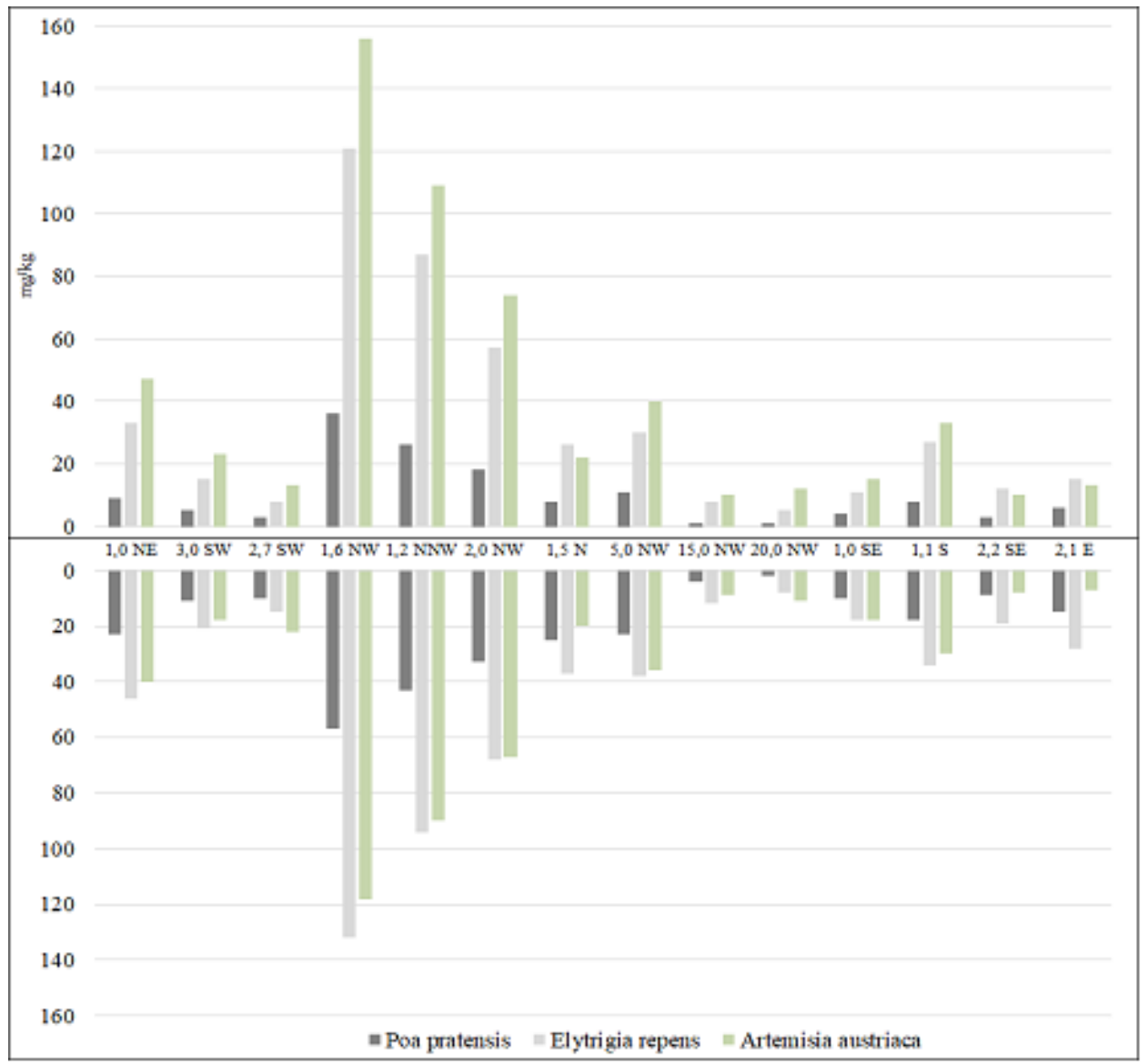

Figure 1: Zn content in various types of wild herbaceous plants in the monitoring sites (above-aboveground part, below-root system), mg/kg.

In addition to the content of elements and their distribution in various parts of plants, the morphometric indicators of plant species were also studied to evaluate the impact of technogenic pollution on plant growth. Whereas the soil is the main factor determining plant growth, the obtained results were grouped according to soil types where the studied plants have been collected. It was determined that all plants growing on unpolluted ordinary chernozem are characterized with maximum morphometric parameters that indicate the most favorable growth conditions for the plants (Table 1). The lowest parameters were noted on alluvial soil. It should be noted that all morphometric parameters on chernozem with background HM content were insignificantly higher than on polluted soil. This fact indicates the technogenic pollution impact on the plants collected on the monitoring sites with the prevailing wind direction.

The length of plant roots on polluted areas with ordinary chernozem corresponded to this indicator on meadow-chernozem soil, and the maximum length of stems, as well as the average and maximum length of leaves, were lower than on meadowchernozem soil.Among the studied plant species, Elytrigia repenswas characterized by 


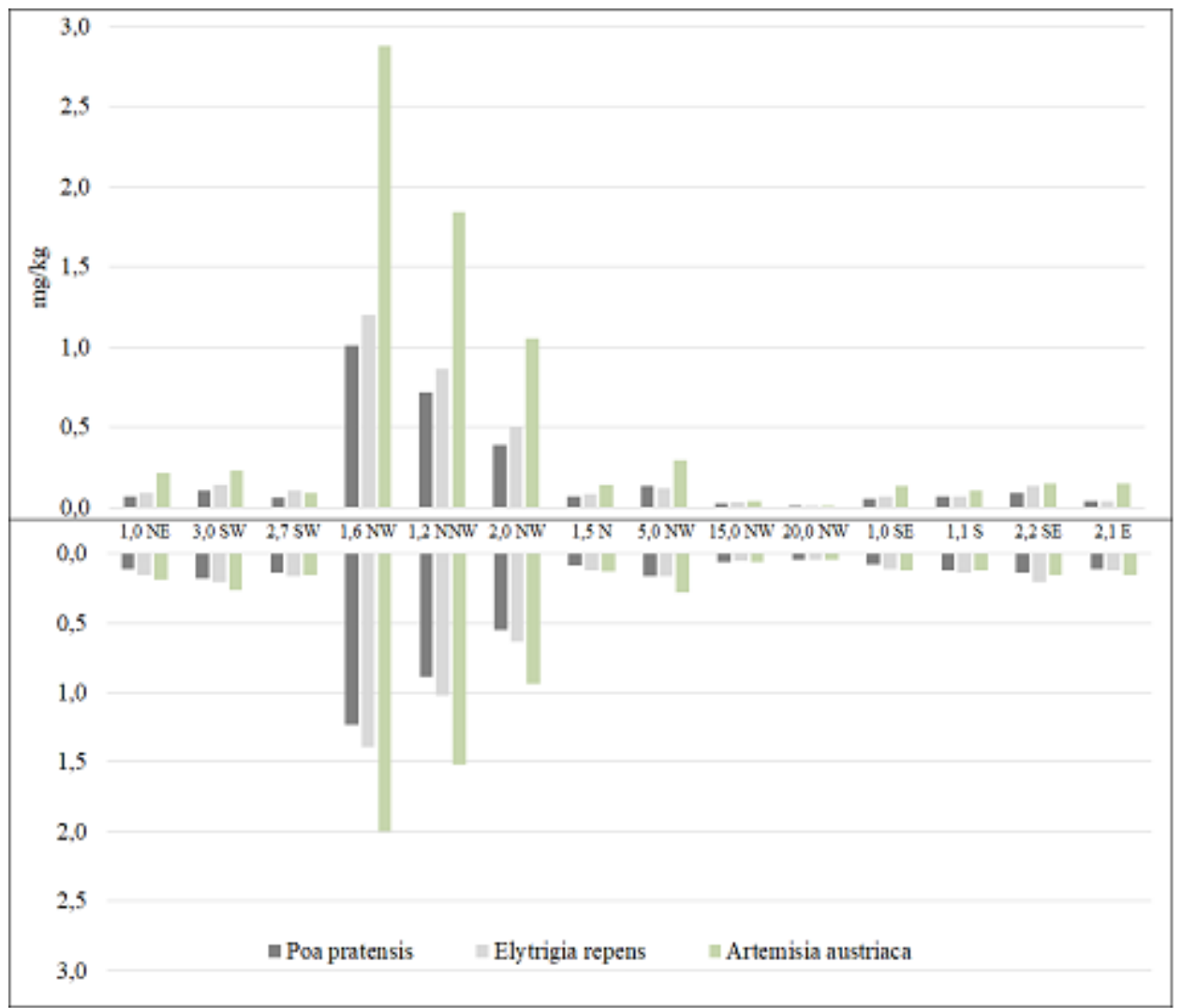

Figure 2: Cd content in various species of wild herbaceous plants in the monitoring sites (aboveaboveground part, below-root system), $\mathrm{mg} / \mathrm{kg}$.

the maximum total plant length and length of the stems, leaves and inflorescences, and Poa pratensis with root length Artemisia austriaca had the lowest values of the morphometric parameters.

\section{Conclusions}

It has been found that long-term technogenic pollution of wild medicinal herbaceous plants in a $5 \mathrm{~km}$ zone occurs mainly in the northwest direction from NchPS. The accumulation of $\mathrm{Zn}$ and $\mathrm{Cd}$ was observed mainly in the aboveground part of Artemisia austriacaplants and in the root system of Elytrigia repensand Poa pratensis. The high content of $\mathrm{Zn}$ and $\mathrm{Cd}$ in these medicinal plants (up to 3.1 and 28.8 MPC, respectively) poses a potential threat to public health that related with insignificant changes in the morphology of medicinal plants due to the higher content of heavy metals which could not be visually analyzed.

This work was financially supported by the Ministry of Science and High Education of Russian Federation, project no. 0852-2020-0029 and grant of the President of Russian Federation no. MK-2818.2019.5. 
TABLE 1: Morphometric parameters of plants on unpolluted ordinary chernozem (background site) and soils of the impact areas of NchPS, cm (average values for all sites).

\begin{tabular}{|c|c|c|c|c|c|c|c|c|c|c|c|c|c|c|c|}
\hline \multirow[t]{2}{*}{ Plant species } & \multicolumn{3}{|c|}{ Total length } & \multicolumn{3}{|c|}{ Root length } & \multicolumn{3}{|c|}{ Stem length } & \multicolumn{3}{|c|}{ Leaf length } & \multicolumn{3}{|c|}{ Inflorescence length } \\
\hline & minimal & average & maximal & minimal & average & maximal & minimal & average & maximal & minimal & average & maximal & minimal & average & maximal \\
\hline \multicolumn{16}{|c|}{ Alluvial soil } \\
\hline $\begin{array}{l}\text { Elytrigia } \\
\text { repens }\end{array}$ & 20.2 & 53.5 & 80.0 & 5.2 & 11.2 & 14.9 & 18.3 & 50.1 & 75.0 & 9.0 & 13.0 & 16.0 & 2.2 & 4.1 & 5.0 \\
\hline $\begin{array}{l}\text { Artemisia } \\
\text { austriaca }\end{array}$ & 20.7 & 41.2 & 50.5 & 8.0 & 9.6 & 11.6 & 19.5 & 37.4 & 43.0 & 2.4 & 4.3 & 7.5 & - & - & \\
\hline Poa pratensis & 14.4 & 44.6 & 55.3 & 10.1 & 18.3 & 26.1 & 10.4 & 39.0 & 49.2 & 12.2 & 15.6 & 17.1 & 1.5 & 2.9 & 3.5 \\
\hline \multicolumn{16}{|c|}{ Meadow chernozem } \\
\hline $\begin{array}{l}\text { Elytrigia } \\
\text { repens }\end{array}$ & 28.8 & 87.3 & 114.3 & 10.3 & 12.8 & 18.6 & 22.4 & 78.6 & 104.0 & 18.5 & 22.5 & 25.2 & 4.4 & 6.4 & 10.3 \\
\hline $\begin{array}{l}\text { Artemisia } \\
\text { austriaca }\end{array}$ & 26.8 & 65.0 & 87.5 & 8.8 & 9.5 & 13.0 & 26.0 & 59.5 & 86.2 & 1.8 & 5.2 & 7.8 & - & - & - \\
\hline Poa pratensis & 63.2 & 83.4 & 107.7 & 21.3 & 24.4 & 27.2 & 58.2 & 75.9 & 102.5 & 8.3 & 19.0 & 23.3 & 4.2 & 4.5 & 5.0 \\
\hline \multicolumn{16}{|c|}{ Ordinary chernozem } \\
\hline $\begin{array}{l}\text { Elytrigia } \\
\text { repens }\end{array}$ & 35.8 & 93.3 & 119.7 & 7.2 & 14.2 & 18.8 & 32.3 & 83.2 & 94.2 & 17.2 & 23.1 & 25.5 & 4.3 & 6.4 & 9.5 \\
\hline $\begin{array}{l}\text { Artemisia } \\
\text { austriaca }\end{array}$ & 33.7 & 64.7 & 80.7 & 7.3 & 10.7 & 14.3 & 26.3 & 54.0 & 76.3 & 2.2 & 3.9 & 4.5 & - & - & \\
\hline Poa pratensis & 44.4 & 74.0 & 104.1 & 16.3 & 22.2 & 34.3 & 35.0 & 77.5 & 91.5 & 11.0 & 17.2 & 19.6 & 3.0 & 5.2 & 6.7 \\
\hline \multicolumn{16}{|c|}{ Ordinary chernozem (background site) } \\
\hline $\begin{array}{l}\text { Elytrigia } \\
\text { repens }\end{array}$ & 47.3 & 123.3 & 136.7 & 13.2 & 18.2 & 38.4 & 42.0 & 113.8 & 165.2 & 17.2 & 23.1 & 25.5 & 4.3 & 6.4 & 9.5 \\
\hline $\begin{array}{l}\text { Artemisia } \\
\text { austriaca }\end{array}$ & 40.0 & 66.7 & 90.8 & 5.9 & 14.0 & 19.6 & 38.1 & 64.0 & 88.3 & 2.2 & 3.9 & 4.5 & - & - & \\
\hline Poa pratensis & 68.4 & 114.0 & 135.5 & 22.5 & 25.0 & 29.3 & 55.6 & 107.2 & 133.8 & 16.4 & 24.5 & 29.0 & 4.2 & 5.2 & 8.7 \\
\hline
\end{tabular}

\section{References}

[1] Zhuikova TV, Zinnatova ER.Accumulating ability of plants under technogenic pollution of soils with heavy metals.Povolzhsky Ecological Journal. 2014;2:196-207.

[2] Zagurskaya YV, Kotsupii OV, Siromlya TI.Leaves of Padus avium (Rosaceae) in technogenically disturbed ecotopes as a source of biologically active substances.Rastitelniy Mir AziatskoyChasty Rossii. 2018;4:102-107.

[3] Methodological guide for determination of heavy metals in agricultural soils and plant products.Moscow: Central Institute for the Agrochemical Service; 1992.

[4] Minkina TM, Mandzhieva SS, Chaplygin VA et al.Accumulation of heavy metals by forb steppe vegetation according to long-term monitoring data.Arid Ecosystems. 2018;8(3):190-202.

[5] Fishkim M.F. Environmental conditions and natural resources of Rostov oblast in 2019. Don Ecological Bulletin. 2020. 12. 276-285.

[6] Baiseitova NM, Sartayeva JM.Phytotoxic action of heavy metals in technogenic pollution. Molodoi Uchenyi. 2014;2:382-384.

[7] Mayachkina NV, Chugunov MV. Features bioassay of soil for the purpose of ecotoxicological assessment.Vestnik Nizhegorodskjgo Gosudarstvennogo Universiteta imeni N.I. Lobachevskogo. 2009;1:84-93. 
[8] Pukalchik M, Mercl F, Terekhova VA, Tlustoš P.Biochar, wood ash and humic substances mitigating trace elements stress in contaminated sandy loam soil: Evidence from an integrative approach.Chemosphere. 2018;203:228-238.

[9] Rao M, Padyana S, Dipin KM, Kumar S, Nayak BB, Varela MF. Antimicrobial compounds of plant origin as efflux pump inhibitors: New avenues for controlling multidrug resistant pathogens.Journal of Antimicrobial Agents. 2018;4(1). 159-164.

[10] Syso Al, Syromlya TI, Myadelets MA, Cherevko AS.Ecological and biogeochemical assessment of elemental and biochemical composition of the vegetation of anthropogenically disturbed ecosystems (based on the example of Achillea millefolium L.).Contemporary Problems of Ecology. 2016;9(5):643-651.

[11] Zhao ZJ, Nan ZR, Wang ZW, Yang YM, Shimizu M.Interaction between Cd and Pb in the soil-plant system: A case study of an arid oasis soil-cole system.Journal of Arid Land. 2014;6(1):59-68. 